http://scholar.ummetro.ac.id/index.php/biolova/

DOI : $10.24127 /$ biolova.v1i2.207

\begin{tabular}{l|lll|}
\hline History Article & Received: Maret 2020 & Approved: Agustus 2020 & Published: Agustus 2020 \\
\hline
\end{tabular}

\title{
PERBEDAAN VARIASI KONSENTRAT DAN LAMA MASA LAKTASI TERHADAP PRODUKSI SUSU KAMBING ETAWA SEBAGAI SUMBER BELAJAR BIOLOGI BERUPA LKPD
}

\author{
Muhammad Firdaus $^{1}$, Agus Sutanto ${ }^{2}$, Agus Sujarwanta ${ }^{3}$ \\ Hening Widowati ${ }^{4}$
}

${ }^{1,2,3,4}$ Program Studi Pendidikan Biologi, Pascasarjana Universitas Muhammadiyah Metro e-mail: ${ }^{1}$ daus.rasya22@gmail.com, ${ }^{2}$ sutanto11@gmail.com, ${ }^{3}$ agussujarwanta@ymail.com,

hwummetro@gmail.com

\begin{abstract}
Abstrak: Penelitian ini bertujuan untuk mengetahui perbedaan variasi konsentrat dan lama masa laktasi terhadap produksi susu kambing etawa; mengetahui interaksi antara variasi konsentrat dan lama masa laktasi terhadap produksi susu kambing etawa; mengetahui hasil penelitian dapat dimanfaatkan sebagai sumber belajar biologi berupa LKPD. Penelitian ini menggunakan metode eksperimen dengan menggunakan Rancangan Acak Lengkap (RAL) dengan faktorial 2x2 dengan 3 ulangan. Sampel yang digunakan ialah 12 ekor kambing etawa Parameter yang diukur ialah volume produksi susu kambing etawa. Hasil perhitungan anova menunjukkan bahwa:ada perbedaan produksi susu kambing etawa antara variasi konsentrat A dan variasi konsentrat B dengan nilai sig. $0,000<\alpha=0,05$; ada perbedaan produksi susu kambing etawa antara masa laktasi 2 dan masa laktasi 4 dengan nilai sig. $0,000<\alpha=0,05$; interaksi antara variasi konsentratdan lama masa laktasiberpengaruhterhadap produksi susu kambing etawa dengan nilai sig. $0,001<\alpha=0,05$; LKPD dinyatakan valid meliputi aspek materi dan desain dengan persentase rata-rata dengan sangat baik.
\end{abstract}

Kata kunci: Konsentrat, laktasi, produksi susu, LKPD

\begin{abstract}
This research aims to determine differences between the variations of concentrate and the duration of lactation period on etawa goat milk production; to know the interaction between the variations of concentrate and the duration of lactation period on etawa goat milk production; to know the results of research which can be used as a source of learning biology in the form of LKPD. This research was used an experimental method using a Completely Randomized Design (CRD) by $2 \times 2$ factorial with 3 replications. The samples which used were 12 etawa goats. The measured parameter was the volume of etawa goat milk production. Anova calculation results showed that: there is a difference in etawa goat milk production between variations of concentrate A and variations of concentrate $B$ with sig values. $0,000<\alpha=0.05$; there is a difference in etawa goat milk production between the lactation period 2 and the lactation period 4 with sig values. 0,000 $<\alpha=0.05$; the interaction between the variations of concentrate and the duration of lactation period affect the production of etawa goat milk with sig. $0.001<\alpha=0.05 ;$ LKPD is stated valid involving the material and design aspects with an average percentage very well.
\end{abstract}

Keywords: Concentrate, lactation, milk production, LKPD

\section{How to Cite}

Firdaus, Muhammad, Agus Sutanto, Agus Sujarwanta dan Hening Widowati. 2020. Perbedaan Variasi Konsentrat dan Lama Masa Laktasi terhadap Produksi Susu Kambing Etawa sebagai Sumber Belajar Biologi Berupa LKPD. Biolova 1(2). 72-81. 
Kambing merupakan hewan yang sering kita jumpai dalam kehidupan sehari-hari, khususnya dalam bidang peternakan. Ternak ruminansia (pemamah biak) yang meliputi sapi, kerbau, domba, dan kambing, mempunyai peran sangat strategis bagi kehidupan ekonomi petani dipedesaan. Awalnya, kambing liar dipelihara untuk diambil dagingnya, setelah itu ternak kambing diusahakan untuk didapatkan susu, daging, kulit, dan bulunya. Kambing etawa merupakan bangsa kambing hasil persilangan antara kambing kacang dengan kambing etawa. Kambing peranakan etawa memiliki sifat antara kambing etawa dengan kambing kacang. Kambing etawa merupakan ternak kambing yang sudah menyebar diseluruh pedesaan di Indonesia dan sudah terkenal sebagai ternak penghasil susu dan penghasil daging. "Kambing ini cocok untuk diternak karena ambingnya besar, putingnya panjang, dan dapat menghasilkan susu 2-3 liter per hari selama masa laktasi" (Mulyono, 2006:11).

Kambing etawa merupakan salah satu ternak yang cukup potensial sebagai penyedia protein hewani baik melalui daging maupun susunya, sesuai dengan pendapat Waluyo (2008:19) menyatakan bahwa "Kambing etawa tipe dwiguna yaitu sebagai penghasil daging dan susu (perah)". Beragamnya produksi susu yang dihasilkan kambing salah satunya disebabkan karena rendahnya kualitas pakan yang diberikan.Pengembangan kambing etawa sebagai penghasil susu belum banyak diperhatikan dan pemeliharaan masih bersifat tradisional. Pakannya sebagian besar hanya rumput lapangan saja sehingga belum bisa mencukupi kebutuhan fisiologis ternak terutama dari sumber energi dan protein. Hewan ternak yang berada dalam kondisi laktasi atau kondisi menyusui aktivitas metabolisme kelenjar ambingnya meningkat, meningkatnya kelenjar ambing ini dipengaruhi oleh kondisi menyusui pada ternak tersebut. Kondisi ini diperlukan pasokan nutrisi yang cukup tinggi dalam upaya memenuhi kebutuhan ternak untuk produksi air susu, sehingga produksi susu yang dihasilkan dapat maksimal.

Ketersediaan karbohidrat mudah terlarut pada hijauan adalah rendah. Karena itu, suplementasi konsentrat yang mengandung campuran bahan-bahan sumber energi, protein serta mineral (mikro dan makro) merupakan salah satu solusi untuk dapat meningkatkan produk fermentasi rumen yang pada giliran berikutnya dapat menyediakan nutrien yang cukup untuk pembentukan air susu, sehingga nantinya diharapkan akan menghasilkan produksi susu yang optimal karena kebutuhan nutrisi terpenuhi. Konsentrat diharapkan dapat bertindak sebagai sumber karbohidrat mudah terlarut, protein lolos degradasi, dan sebagai sumber glukosa untuk bahan baku produksi susu.

\section{METODE PENELITIAN}

Penelitian ini termasuk ke dalam penelitian eksperimen karena mengamati produksi susu kambing etawa yang diberi variasi konsentrat pada masa laktasi yang berbeda. Penelitian ini menggunakan Rancangan Acak Lengkap (RAL) pola faktorial 2x2 masing-masing dengan 3 ulangan. Penelitian ini bertujuan untuk mengetahui apakah ada perbedaan produksi susu kambing etawa antara variasi konsentrat dan masa laktasi yang diberikan.

Faktor A adalah variasi konsentrat

$\mathrm{A} 1=5$ ons ampas tahu +5 ons ampas singkong +5 ons bekatul

$\mathrm{A} 2=10$ ons ampas tahu +3 ons ampas singkong +2 ons bekatul

Faktor B adalah masa laktasi

B1 = masa laktasi ke-2

$\mathrm{B} 2$ = masa laktasi ke-4

Parameter penelitian yang diukur adalah volume produksi susu yang dihasilkan. Penelitian dilakukan di rumah peternakan kambing etawa milik Bapak Purnawan Ari Nugroho.Prosedur kerja yang dilakukan selama penelitian adalah menempatkan induk kambing yang telah dipilih secara acak dalam kandang individu sesuai perlakuan. Pemberian konsentrat dilakukan tiap pada pagi dan sore hari, sebelum pemberian pakan hijauan. Kambing-kambing etawa setiap hari diberikan pakan konsentrat dengan variasi konsentrat yang berbeda-beda pada masa laktasi yang berbeda-beda pula sehingga nanti dapat diketahui produksi susu tiap perlakuannya.

Data produksi susu kambing etawa dianalisis dengan Analisis Varians 2 arah. Teknik analisis data dibantu dengan Software Statistical Productand Service Solutions versi 16.0, atau disingkat SPSS 16.0.Adapun analisis uji Anava yang digunakan adalah uji prasyarat 
(uji normalitas, uji homogenitas), uji hipotesis dan uji lanjut (Tukey).

\section{HASIL}

Penelitian ini menggunakan sampel kambing etawa sebagai obyek penelitian, parameter yang diamati ialah produksi susu kambing etawa. Hasil penelitian ialah sebagai berikut:

\section{Produksi Susu pada Perlakuan A1}

Hasil rata-rata produksi susu kambing etawa yang diberikan perlakuan A1 yaitu pemberian konsentrat A dengan variasi pakan 5 ons ampas tahu +5 ons ampas singkong +5 ons bekatul dilihat pada Tabel 1 .

Tabel 1. Produksi Susu Perlakuan A1

\begin{tabular}{|c|c|}
\hline No. Sampel & $\begin{array}{c}\text { Rerata Produksi } \\
\text { Susu (ml) }\end{array}$ \\
\hline 1 & 748 \\
\hline 2 & 752 \\
\hline 3 & 775 \\
\hline 4 & 790 \\
\hline 5 & 798 \\
\hline 6 & 806 \\
\hline Rerata & 778 \\
\hline
\end{tabular}

\section{Produksi Susu pada Perlakuan A2}

Hasil rata-rata produksi susu kambing etawa yang diberikan perlakuan A2 yaitu pemberian konsentrat $\mathrm{B}$ dengan variasi pakan 10 ons ampas tahu +3 ons ampas singkong +2 ons bekatul dilihat pada Tabel 2 .

Tabel 2. Produksi Susu Perlakuan A2

\begin{tabular}{|c|c|}
\hline No. Sampel & $\begin{array}{c}\text { Rerata Produksi } \\
\text { Susu (ml) }\end{array}$ \\
\hline 1 & 912 \\
\hline 2 & 916 \\
\hline 3 & 919 \\
\hline 4 & 1011 \\
\hline 5 & 1016 \\
\hline 6 & 1030 \\
\hline Rerata & 967,3 \\
\hline
\end{tabular}

\section{Produksi Susu pada Perlakuan B1}

Hasil rata-rata produksi susu kambing etawa yang diberikan perlakuan B1 yaitu pada lama masa laktasi ke-2 dilihat pada Tabel 3.
Tabel 3. Produksi Susu Perlakuan B1

\begin{tabular}{|c|c|}
\hline No. Sampel & $\begin{array}{c}\text { Rerata Produksi } \\
\text { Susu (ml) }\end{array}$ \\
\hline 1 & 748 \\
\hline 2 & 752 \\
\hline 3 & 775 \\
\hline 4 & 912 \\
\hline 5 & 916 \\
\hline 6 & 919 \\
\hline Rerata & 837 \\
\hline
\end{tabular}

\section{Produksi Susu pada Perlakuan B2}

Hasil rata-rata produksi susu kambing etawa yang diberikan perlakuan B2 yaitu pada lama masa laktasi ke-4 dilihat pada Tabel 4.

Tabel 4. Produksi Susu Perlakuan B2

\begin{tabular}{|c|c|}
\hline No. Sampel & $\begin{array}{c}\text { Rerata Produksi Susu } \\
(\mathrm{ml})\end{array}$ \\
\hline 1 & 790 \\
\hline 2 & 798 \\
\hline 3 & 806 \\
\hline 4 & 1011 \\
\hline 5 & 1016 \\
\hline 6 & 1030 \\
\hline Rerata & 908,5 \\
\hline
\end{tabular}

\section{Produksi Susu pada Perlakuan A1B1}

Hasil rata-rata produksi susu kambing etawa yang diberikan perlakuan A1B1 yaitu pemberian konsentrat A dengan variasi pakan 5 ons ampas tahu +5 ons ampas singkong +5 ons bekatul pada masa laktasi ke-2 dilihat pada Tabel 5.

Tabel 5. Produksi Susu Perlakuan A1B1

\begin{tabular}{|c|c|}
\hline No. Sampel & $\begin{array}{c}\text { Rerata Produksi } \\
\text { Susu (ml) }\end{array}$ \\
\hline 1 & 748 \\
\hline 2 & 752 \\
\hline 3 & 775 \\
\hline Rerata & 758,3 \\
\hline
\end{tabular}

\section{Produksi Susu pada Perlakuan A1B2}

Hasil rata-rata produksi susu kambing etawa yang diberikan perlakuan A1B2 yaitu pemberian konsentrat A dengan variasi pakan 5 ons ampas tahu +5 ons ampas singkong +5 ons 
bekatul pada masa laktasi ke-4 dilihat pada Tabel 6.

Tabel 6. Produksi Susu Perlakuan A1B2

\begin{tabular}{|c|c|}
\hline No. Sampel & $\begin{array}{c}\text { Rerata Produksi } \\
\text { Susu (ml) }\end{array}$ \\
\hline 1 & 790 \\
\hline 2 & 798 \\
\hline 3 & 806 \\
\hline Rerata & 798 \\
\hline
\end{tabular}

\section{Produksi Susu pada Perlakuan A2B1}

Hasil rata-rata produksi susu kambing etawa yang diberikan perlakuan A2B1 yaitu pemberian konsentrat $\mathrm{B}$ dengan variasi pakan 10 ons ampas tahu +3 ons ampas singkong +2 ons bekatul pada masa laktasi ke- 2 dilihat pada Tabel 7.

Tabel 7. Produksi Susu Perlakuan A2B1

\begin{tabular}{|c|c|}
\hline No. Sampel & $\begin{array}{c}\text { Rerata Produksi } \\
\text { Susu (ml) }\end{array}$ \\
\hline 1 & 912 \\
\hline 2 & 916 \\
\hline 3 & 919 \\
\hline Rerata & 915,67 \\
\hline
\end{tabular}

\section{Produksi Susu pada Perlakuan A2B2}

Hasil rata-rata produksi susu kambing etawa yang diberikan perlakuan A2B2 yaitu pemberian konsentrat $\mathrm{B}$ dengan variasi pakan 10 ons ampas tahu +3 ons ampas singkong +2 ons bekatul pada masa laktasi ke-4 dilihat pada Tabel 8.

Tabel 8. Produksi Susu Perlakuan A2B2

\begin{tabular}{|c|c|}
\hline $\begin{array}{c}\text { No. } \\
\text { Sampel }\end{array}$ & $\begin{array}{c}\text { Rerata Produksi } \\
\text { Susu }(\mathrm{ml})\end{array}$ \\
\hline 1 & 1011 \\
\hline 2 & 1016 \\
\hline 3 & 1030 \\
\hline Rerata & 1019 \\
\hline
\end{tabular}

Adapun hasil pengujian hipotesis menggunakan SPSS versi 20.0 dengan analisis varian dua arah yang digunakan untuk mengetahui ada tidaknya pengaruh variasi konsentrat terhadap produksi susu kambing etawa, ada atau tidaknya pengaruh masa laktasi terhadap produksi susu kambing etawa, dan ada atau tidaknya interaksi antara pengaruh variasi konsentrat dan masa laktasi terhadap produksi susu kambing etawa. Hasil ada atau tidaknya pengaruh dan interaksi dapat dilihat pada tabel output SPSS dengan melihat nilai signifikansinya, dengan kriteria uji sebagai berikut:

Tabel 9. Uji Hipotesis Variasi Konsentrat dan MasaLaktasi terhadap Produksi Susu Kambing Etawa

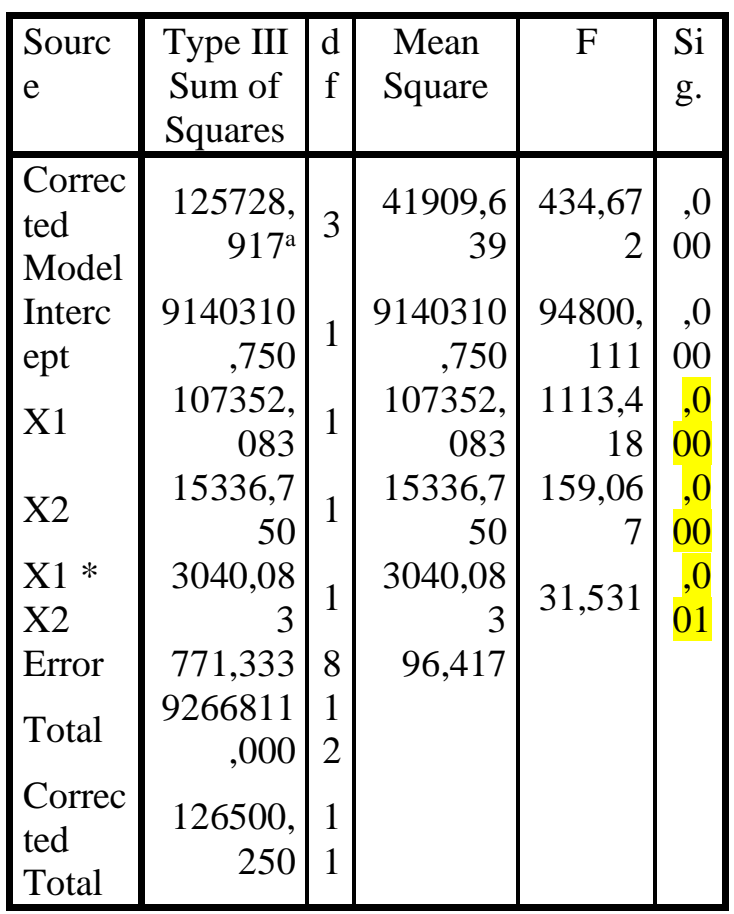

a. R Squared = ,994 (Adjusted R Squared = ,992) 
Berdasarkan hasiloutput SPSS pada Tabel 9 (X1)didapatkan $F_{\text {hitung }}=11113,418$ dengan nilai sig. $0,000<\alpha=0,05$ sehingga $\mathrm{H}_{0}$ ditolak yang berarti ada perbedaan produksi susu kambing etawa antara variasi konsentrat A dan variasi konsentrat B.Berdasarkan hasil output SPSS pada Tabel 9 (X2), untuk hipotesis kedua didapatkanF $F_{\text {hitung }}=159,067$ dengan nilai sig. (signifikansi) $0,000<\alpha=0,05$ sehingga $\mathrm{H}_{0}$ ditolak yang berarti ada perbedaan produksi susu kambing etawa antara masa laktasi 2 dan masa laktasi 4.Berdasarkan hasil output SPSS pada Tabel $9(\mathrm{X} 1 * \mathrm{X} 2)$, untuk hipotesis ketiga didapatkan $F_{\text {hitung }}=31,531$ dengan nilai sig. (signifikansi) $0,001<\alpha=0,05$ sehingga $\mathrm{H}_{0}$ ditolak yang berarti ada pengaruh interaksi antara variasi konsentrat dan masa laktasi terhadap produksi susu kambing etawa.

Adapun hasil uji lanjut tukey dapat dilihat pada Tabel 10 ialah sebagai berikut.

Tabel 10. Rekapitulasi Hasil Uji Lanjut Tukey

\begin{tabular}{|c|l|l|l|}
\hline No & $\begin{array}{c}\text { Perbandinga } \\
\text { n }\end{array}$ & Hasil & $\begin{array}{c}\text { Keteranga } \\
\text { n }\end{array}$ \\
\hline & & Fhit $=$ & \\
1. & A1B1 vs & 0 & Signifikan \\
& A2B1 & Sig. $=$ & \\
& & $0,000<$ & \\
& & $\alpha 0,05$ & \\
& & Fhit $=$ & \\
2. & A1B2vs & 910.08 & \\
& A2B2 & 1 & Signifikan \\
& & Sig.= & \\
& & $0,000<$ & \\
\hline
\end{tabular}

Berdasarkan hasiloutput SPSS pada Tabel 10 didapatkan $F_{\text {hitung }}=330,540$ dengan nilai sig. (signifikansi) $0,000<\alpha=0,05$, sehingga tolak $\mathrm{H}_{0}$ yang berarti ada perbedaan produksi susu kambing etawa antara variasi konsentrat A dan variasi konsentrat B ditinjau dari masa laktasi 2. Produksi susu tertinggi ialah pada perlakuan A2B1. Berdasarkan hasiloutput SPSS pada Tabel 10 didapatkan $F_{\text {hitung }}=910,081$ dengan nilai sig. (signifikansi) $0,000<\alpha=$ 0,05 ,sehingga tolak $\mathrm{H}_{0}$ yang berarti ada perbedaan produksi susu kambing etawa antara variasi konsentrat $\mathrm{A}$ dan variasi konsentrat $\mathrm{B}$ ditinjau dari masa laktasi 4. Produksi susu tertinggi ialah pada perlakuan A2B1.

\section{PEMBAHASAN}

Perbedaan Produksi Susu Kambing Etawa antara Variasi Konsentrat A dan Variasi Konsentrat B

Dalam konteks data empirik hasil penelitian, diperoleh rerata produksi susu kambing etawa yang tertinggi diperoleh pada perlakuan A2, yakni pemberian konsentrat dengan perbandingan 10 ons ampas tahu, 3 ons ampas singkong, 2 ons bekatul, dengan pror " susu sebesar $967,3 \mathrm{ml}$, sedangkan produksi susu terendah yaitu pada perlakuan A1 dengan perbandingan 5 ons ampas tahu, 5 ons ampas singkong dan 5 ons bekatul dengan rerata produksi susu sebesar $778 \mathrm{ml}$

Pemberian pakan konsentrat sangat baik untuk meningkatkan produksi susu kambing etawa, karena pakan konsentrat merupakan pakan penguat yang terdiri dari bahan pakan yang kaya akan karbohidrat dan protein. Hasil penelitian ini sesuai dengan yang dilakukan oleh Andriani, Latif, Fachri \& Sulaksana (2014:20) bahwa "Pemberian pakan berkualitas pada kambing etawa saat laktasi dapat meningkatkan produksi susu yang dihasilkan".

Pemberian pakan yang berkualitas secara tidak langsung dapat memberikan dampak yang baik untuk produksi susu kambing etawa, karena kandungan proteinnya yang dimilikinya sangat tinggi. Protein sangat dibutuhkan kambing untuk pembentukan susu. Protein yang tinggi pada konsentrat diperoleh dari bahan pakan yaitu ampas tahu, ampas tahu diketahui mempunyai kandungan protein yang tinggi sebanyak 21,29\% (Ali, Nurul, Nuraliah, 2017). Protein dibutuhkan untuk membantu proses pembentukkan susu bisa diperoleh dari pakan, sehingga kualitas dan kuantitas pakan yang diberikan harus benar-benar mencukupi kebutuhan kambing.

Konsentrat serta hijauan merupakan komponen penting di dalam penyusunan ransum makanan ternak. Konsentrat merupakan bahan pakan yang digunakan bersama bahan pakan lain untuk meningkatkan keserasian gizi dari keseluruhan pakan dan dimaksudkan untuk 
disatukan atau dicampur sebagai suplemen atau bahan pelengkap.

\section{Perbedaan Produksi Susu Kambing Etawa antara Masa Laktasi 2 dan Masa Laktasi 4}

Dalam konteks data empirik hasil penelitian, diperoleh rerata produksi susu kambing etawa yang tertinggi diperoleh pada perlakuan B2, yakni pada masa laktasi 4, dengan produksi susu sebesar $908,5 \mathrm{ml}$, sedangkan produksi susu terendah yaitu pada perlakuan B1 yakni pada masa laktasi 2, dengan produksi susu sebesar $837 \mathrm{ml}$. Hasil penelitian membuktikan bahwa masa laktasi yang menghasilkan produksi susu kambing etawa tertinggi adalah lama laktasi ke-4, karena berkaitan dengan kedewasaan kambing. Semakin lama masa laktasi atau semakin matang masa pertumbuhan kambing maka semakin banyak produksi susu yang dihasilkan. Sesuai dengan penelitian yang dilakukan oleh Hadiannuloh, Willyan, Didin (2015) bahwa "Produksi susu pada laktasi ke-1, ke-2, dan ke-3 nilainya kian meningkat". Volume produksi susu kambing antara lain dipengaruhi oleh periode laktasi, periode laktasi berkaitan erat dengan umur kambing karena periode laktasi meningkat seiring dengan meningkatnya umur kambing dan puncak produksi susu pada kambing biasanya terjadi pada laktasi ke-3 sampai ke-5 atau saat kambing berumur 5-7 tahun dan selanjutnya akan terjadi penurunan produksi susu (Disa, 2016).

Peningkatan produksi susu ini berkaitan sekali dengan kematangan masa pertumbuhan kambing sehingga berpengaruh sekali pada produksi susu yang dihasilkan. Sesuai dengan pernyataan Sodiq (2009) bahwa "Semakin lama masa laktasi, akan semakin banyak total produksi yang dihasilkan". Sodiq (2009) juga menerangkan bahwa "Produktivitas mencapai puncaknya ketika kambing berumur 5-7 tahun yakni pada masa laktasi ke-3 atau ke-5". Jumlah susu yang dihasilkan setiap kambing berbedabeda, jumlah susu yang berbeda ini banyak faktor yang mempengaruhi salah satunya adalah umur atau kedewasaan kambing.

\section{Pengaruh Interaksi Antara Variasi Konsentrat dan Masa Laktasi terhadap Produksi Susu Kambing Etawa}

Adanya interaksi antara variasi konsentrat dan masa laktasi terhadap produksi susu kambing etawa disebabkan karena kedua variabel perlakuan yaitu variasi konsentrat dan masa laktasi bersama-sama memberikan pengaruh yang signifikan terhadap produksi susu kambing etawa. Dalam konteks data empirik hasil penelitian, diperoleh rerata produksi susu kambing pada perlakuan A1B1, A1B2, A2B1 dan A2B2 produksi susu kian meningkat (dilihat pada Tabel 11, 12, 13 dan 14) hal ini membuktikan bahwa terjadi interaksi yang sinergis terhadap kedua perlakuan.

Variasi konsentrat yang diberikan pada masing-masing perlakuan terbukti mampu menghasilkan perbedaan pada peningkatan volume susu yang dihasilkan. Pakan konsentrat adalah pakan dengan kandungan serat kasar yang rendah, sehingga konsentrat lebih mudah dicerna oleh ternak yang digunakan untuk pakan pelengkap yang mengandung nutrisi karena secara umum produksi susu kambing etawa dipengaruhi oleh kualitas pakan yang diberikan, dimana sebagian besar prokursor untuk sintesis air susu dalam kelenjar ambing berasal dari darah yang sangat tergantung pada kualitas pakan dan penterapan di dalam tubuh, pakan yang berkualitas memberikan nutrien darah yang lebih tinggi dan berkorelasi terhadap proses sintesis susu di dalam sel sekretoris kelenjar ambing yang akhirnya meningkatkan produksi susu dan kualitas susu yang dihasilkan (Sahda, 2016).

Masa laktasi yang memberikan pengaruh terhadap produksi susu kambing etawa yang dhasilkan, karena selain pakan yang diberikan faktor lain yang mempengaruhi produksi susu adalah masa laktasi. Produksi susu dipengaruhi mutu genetik, umur induk, ukuran dimensi ambing, bobot hidup, lama laktasi, serta tata laksana yang diberlakukan pada ternak yang meliputi perkandangan, pakan dan kesehatan ternak (Phalepi (dalam Fitriyanto,2013)). Semakin lama masa laktasi atau semakin matang masa pertumbuhan kambing maka semakin banyak produksi susu yang dihasilkan.

Perbedaan Produksi Susu Kambing Etawa antara Variasi Konsentrat A dan Variasi Konsentrat B ditinjau dari Masa Laktasi 2

Dalam konteks data empirik hasil
penelitian, diperoleh rerata produksi susu 
kambing etawa yang tertinggi diperoleh pada perlakuan A2B1, yakni pemberian konsentrat dengan perbandingan 10 ons ampas tahu, 3 ons ampas singkong, 2 ons bekatul yang dipadukan dengan masa laktasi 2 dengan rerata produksi susu sebesar 915,67 ml, sedangkan produksi susu terendah yaitu pada perlakuan A1B1 yakni pemberian konsentrat dengan perbandingan 5 ons ampas tahu, 5 ons ampas singkong, 5 ons bekatul yang dipadukan dengan masa laktasi 2 dengan rerata produksi susu sebesar 758,33 ml

Hal ini membuktikan bahwa perlakuan A2B1 lebih baik dalam menghasilkan susu. Perbedaan volume susu yang dihasilkan disebabkan oleh pemberian konsentrat yang berbeda. Perlakuan A2B1 menggunakan bahan pakan ampas tahu 10 ons, ampas singkong 3 ons dan bekatul 2 ons, sehingga diketahui bahwa pemberian protein yang berasal dari ampas tahu sangat tinggi sehingga mempengaruhi produksi susu yang dihasilkan, karena protein yang terkandung dalam ampas tahu sangat dibutuhkan sekali untuk memproduksi susu, sesuai dengan hasil penelitian yang dilakukan oleh Ali, Nurul, dan Nuraliah (2017) bahwa "pemberian ampas tahu pada kambing etawa yang sedang dalam laktasi memberikan pengaruh positif terhadap produksi susu dan pertumbuhan berat badan". Pemberian ampas tahu dalam ransum menambah energi yang terkandung dalam ransum sehingga dapat mempengaruhi produksi susu. Hal ini dikarenakan produksi susu dipengaruhi oleh beberapa faktor salah satunya adalah pakan, zat-zat nutrisi yang terkandung dalam pakan mempengaruhi aktifitas metabolisme dan sel-sel kelenjar ambing untuk mensintesis susu.

\section{Perbedaan Produksi Susu Kambing Etawa antara Variasi Konsentrat A dan Variasi Konsentrat B ditinjau dari Masa Laktasi 4}

Dalam konteks data empirik hasil penelitian, diperoleh rerata produksi susu kambing etawa yang tertinggi diperoleh pada perlakuan A2B2, yakni pemberian konsentrat dengan perbandingan 10 ons ampas tahu, 3 ons ampas singkong, 2 ons bekatul yang dipadukan dengan masa laktasi 4 dengan rerata produksi susu sebesar 1019,00 ml, sedangkan produksi susu terendah yaitu pada perlakuan A1B2 yakni pemberian konsentrat dengan perbandingan 5 ons ampas tahu, 5 ons ampas singkong, 5 ons bekatul yang dipadukan dengan masa laktasi 4 dengan rerata produksi susu sebesar 798,00 ml.

Hal ini membuktikan bahwa perlakuan A2B2 lebih baik karena menghasilkan volume susu lebih banyak. Perbedaan produksi yang dihasilkan disebabkan oleh pemberian konsentrat yang berbeda yang mengandung pakan dengan kandungan protein yang tinggi serta dipadukan dengan masa laktasi kambing yang menunjukan kambing sudah dewasa yang secara tidak langsung mempengaruhi produktivitas kambing, sesuai dengan pendapat Kartiko, Akbarillah, dan Hidayat (2018) yang menyatakan bahwa "performa produksi susu kambing perah akan optimal apabila didukung oleh ketersediaan pakan dalam jumlah yang cukup dan kualitasnya baik". Ramadhan, Suprayogi, dan Sustiyah (2013) menyatakan bahwa "Produksi susu dipengaruhi bangsa, individu, masa laktasi, umur, berat badan, pakan, lama pengeringan, frekuensi

pemerahan, dan penyakit". Secara umum produksi susu kambing sangat dipengaruhi oleh pakan dan kualitas pakan yang diberikan, dan sudah dibuktikan bahwa pemberian pakan yang berkualitas yang kemudian diberikan kepada kambing dewasa maka akan berkorelasi terhadap proses sintesis susu di dalam sel sekretoris yang akhirnya akan meningkatkan produksi susu yang dihasilkan.

\section{Implementasi Hasil Penelitian sebagai Sumber Belajar Biologi}

Hasil penelitian yang diperoleh dapat dikembangkan sebagai sumber belajar biologi berupa produk LKPD (Lembar kerja Peserta Didik) yang dikembangkan sesuai model pengembangan 4-D dipadukan dengan perkembangan kurikulum 2013 yang berpedoman kepada pemecahan masalah berbasis metode ilmiah (saintifik approach).

Adapun Kompetensi Dasar (KD) pada materi ini adalah 4.7 Menyajikan laporan hasil uji zat makanan yang terkandung dalam berbagai jenis bahan makanan dikaitkan dengan kebutuhan energi setiap individu serta teknologi pengolahan pangan dan kemanan pangan. Proses pembelajaran tersebut diarahkan pada tiga ranah dimensi pengetahuan yaitu, kognitif, afektif, dan psikomotorik.

Adapun LKPD yang disusun berbasis saintifik dengan ruang lingkup pembelajaran dalam tema makanan dan sistem pencernaan 
makanan untuk mengembangkan aspek sikap, pengetahuan, dan keterampilan dilihat pada Tabel 11.

Tabel 11. Pengembangan Aspek Sikap, Pengetahuan, Keterampilan yang dipadukan dengan Saintifik Approach

\begin{tabular}{|c|c|c|}
\hline Materi Pembelajaran & Kegiatan Pembelajaran & $\begin{array}{l}\text { Kompetensi yang } \\
\text { Dikembangkan }\end{array}$ \\
\hline $\begin{array}{l}\text { - Makanan dan zat } \\
\text { makanan. } \\
\text { - Menyusun menu } \\
\text { makanan seimbang. } \\
\text { - Sistem pencernaan } \\
\text { makanan pada hewan } \\
\text { ruminansia. }\end{array}$ & $\begin{array}{l}\text { Mengamati } \\
\text { Membaca buku teks dan } \\
\text { sumber bacaan lainnya } \\
\text { tentang makanan dan zat } \\
\text { makanan, makanan } \\
\text { seimbang, sistem } \\
\text { pencernaan pada hewan } \\
\text { ruminansia.Mengamati } \\
\text { pemberian makanan } \\
\text { bernutrisi untuk } \\
\text { produktivitas hewan } \\
\text { ruminansia. } \\
\text { Menanya } \\
\text { Peserta didik dimotivasi } \\
\text { untuk membuat } \\
\text { pertanyaan } \\
\text { tentang:Pentingnya } \\
\text { menyusun makanan } \\
\text { seimbang, bagaimana } \\
\text { proses berlangsungnya } \\
\text { sistem pencernaan hewan } \\
\text { ruminansia. } \\
\text { Mengumpulkan Data } \\
\text { (Eksperimen/Eksplorasi) } \\
\text { Diskusi mengenai } \\
\text { menyusun makanan } \\
\text { seimbang serta sistem } \\
\text { pencernaan hewan } \\
\text { ruminansia.Mendesain } \\
\text { kegiatan percobaan } \\
\text { sederhana untuk melihat } \\
\text { pengaruh pemberian } \\
\text { ampas tahu terhadap } \\
\text { produksi susu kambing } \\
\text { etawa. } \\
\text { Mengasosiasi } \\
\text { Mendiskusikan hasil } \\
\text { hasil-hasil kegiatan } \\
\text { tentang makanan dan zat } \\
\text { makanan, menu makanan } \\
\text { seimbang untuk hewan } \\
\text { ruminansia untuk }\end{array}$ & $\begin{array}{l}\text { Sikap: } \\
\text { Mandiri, kerja sama, } \\
\text { responsif, tanggung jawab, } \\
\text { kecermatan, kesungguhan, } \\
\text { percaya diri. } \\
\text { Pengetahuan: } \\
\text { Mengetahui pentingnya } \\
\text { makanan dan zat makanan, } \\
\text { mampu menyusun menu } \\
\text { makanan seimbang untuk } \\
\text { kelengkapan nutrisi, serta } \\
\text { mengetahui sistem } \\
\text { pencernaan pada hewan } \\
\text { ruminansia. } \\
\text { Keterampilan: } \\
\text { Mampu mengidentifikasi } \\
\text { berbagai jenis makanan dan } \\
\text { zat kandungannya untuk } \\
\text { kelengkapan nutrisi hewan } \\
\text { ruminansia. }\end{array}$ \\
\hline
\end{tabular}




\begin{tabular}{|l|l|l|}
\hline & membentuk/memperbaiki & \\
& pemahaman tentang & \\
makanan dan sistem & pencernaan makanan & \\
hewan ruminansia. & \\
Mengkomunikasikan & \\
Menyampaikan hasil & \\
kesimpulannya secara & \\
& lisan mengenai makanan & \\
& dan zat makanan, menu & \\
& makanan seimbang untuk & \\
hewan ruminansia. & \\
\hline
\end{tabular}

\section{KESIMPULAN}

Berdasarkan hasil penelitian yang dilakukan didapatkan kesimpulan bahwa ada perbedaan produksi susu kambing etawa antara pemberian variasi konsentrat dan masa laktasi yang berbeda-beda. Interaksi antara variasi konsentrat dan masa laktasi berpengaruh terhadap produksi susu kambing etawa.Produksi susu kambing etawa pada laktasi ke-2 dan ke-4 yang diberikan konsentrat $\mathrm{B}$ lebih tinggi dari pada yang diberikan konsentrat A.Hasil penelitian dapat dimanfaatkan sebagai sumber belajar biologi berupa LKPD.

\section{SARAN}

Berdasarkan kesimpulan yang diperoleh selama melaksanakan penelitian dan hasil penelitian, maka saran-saran yang dapat disampaikan ialah sabagai berikut:

1. Bagi peneliti selanjutnya, konsentrat yang digunakan sebaiknya tidak menggunakan variasi ampas tahu yang sedikit, karena semakin banyak ampas tahu yang diberikan maka volume produksi susu yang dihasilkanpun juga akan baik.

2. Bagi peneliti peternak, adapun saran yang diberikan:

a. Untuk meningkatkan produksi susu kambing etawa pada masa laktasi ke-2 dapat diberikan ransum konsentrat dengan komposisi 10 ons ampas tahu, 3 ons ampas singkong, dan 2 ons bekatul.

b. Untuk meningkatkan produksi susu kambing etawa pada masa laktasi ke-4 dapat diberikan ransum konsentrat dengan komposisi 10 ons ampas tahu, 3 ons ampas singkong, dan 2 ons bekatul.

\section{DAFTAR PUSTAKA}

Ali, Najmah, Nurul Munawarah \& Nuraliah Sofyan. 2017. Pengaruh Pemberian Ampas Tahu terhadap Produksi Air Susu dan Pertambahan Badan Kambing Peranakan Etawa (PE). Jurnal SAINTEK Peternakan dan Perikanan. Vol. 1. Juni 2017. Hal. 23-26.

Andriani, A Latif, S. Fachri, dan I. Sulaksana. 2014. Peningkatan Produksi dan Kualitas Susu Kambing Peranakan Etawa sebagai Respon Perbaikan Kualitas Pakan. Jurnal Ilmiah ilmuilmu Peternakan. Vol. XVII. No. 1. Mei 2014. Hal. 15-21.

Disa, Putra Rama. 2016. Kualitas Kambing Peranakan Etawa pada Berbagai Periode laktasi ditinjau dari Sifat Fisik di Desa Sungai Langka Kecamatan Gedong Tataan Kabupaten Pesawaran. Skripsi tidak diterbitkan. Lampung: Fakultas Pertanian Universitas Lampung.

Fitriyanto. 2013. Kajian Viskositas dan Berat Jenis Susu Kambing Peranakan Etawa (PE) Pada Awal, Puncak dan Akhir Laktasi. Jurnal Ilmiah Peternakan. Vol. 1. April 2013. Hal. 299-306.

Hardiannuloh Rizki, Wilyan Djaja, \& Didin S. Tasripin. 2015. Performa Produksi Susu dan Konsumsi pada Periode Laktasi 1, 2 dan 3 Kambing Peranakan Etawa (PE) yang diberi Pakan Batang Pisang Fermentasi di Kelompok Pembibitan Kambing Perah As-salam. Skripsi tidak 
diterbitkan. Bandung: Fakultas

Peternakan Universitas Padjadjaran.

Kartiko, Akbarillah \& Hidayat (2018). Pengaruh Penggunaan Bungkil Inti Sawit sebagai Pengganti Ampas tahu dalam Ransum terhadap Produksi Susu Kambing Nubian. Jurnal Sains Peternakan Indonesia. Fakultas Pertanian Universitas Bengkulu. Volume 13. Nomor 3. Juli-September 2018. Hal 229-237. P-ISSN 1978-3000. e-ISSN 2528-7109.

Mulyono Subangkit \& Sarwono, 2006. Penggemukan Kambing Potong. Jakarta: Penebar Swadaya.

Ramadhan, B.G, T.H. Suprayogi, A. Sustiyah. 2013. Tampilan Produksi Susu dan Kadar Lemak Susu Kambing Peranakan Etawa Akibat Pemberian Pakan dengan Imbangan Hijauan dan Konsentrat yang Berbeda. Animal Agriculture Journal. Vol 2. No 1. 2013. Hal 353-361.

Sahda, H. 2016. Sukses Pembibitan dan Pembesaran Kambing Etawa. Depok: Lumenta Publishing.

Sodiq, Akhmad. Zainal Abidin. 2009. Meningkatkan Produksi Susu Kambing Peranakan Etawa. Jakarta: Agromedia Pustaka.

Waluyo Kusno. 2008. Budidaya Kambing. Bandung: Epsilon Grup. 